ISSN: 1978-6298 (Print), 2686-133X (Online)

\title{
GAMBARAN TINGKAT PENGETAHUAN TENTANG KARIES GIGI \\ DAN JUMLAH KARIES GIGI PADA SISWA KELAS IV SD MUHAMMADIYAH TEGALREJO
}

\author{
${ }^{1}$ Ikrima Nanda Islami, ${ }^{2}$ Suharyono, ${ }^{3}$ Furaida Khasanah \\ Poltekkes Kemenkes Yogyakarta \\ email: ikrimananda75@gmail.com
}

\author{
Article History \\ Dikirim, Desember $08^{\text {th }}, 2019$ \\ Ditinjau, Desember $13^{\text {th }}, 2019$ \\ Diterima,Desember $19^{\text {th }}, 2019$
}

\begin{abstract}
ABSTRAK
Tingkat pengetahuan merupakan salah satu kriteria umum yang mempengaruhi sikap menjaga kesehatan gigi seseorang atau komunitas. Masalah utama kesehatan gigi dan mulut anak ialah karies gigi. Karies gigi disebabkan oleh aktivitas metabolisme bakteri dalam plak yang menyebabkan terjadinya demineralisasi email. Penelitian ini bertujuan diketahuinya gambaran tingkat pengetahuan tentang karies gigi dan jumlah karies gigi pada siswa kelas IV SD Muhammadiyah Tegalrejo. Jenis penelitian ini bersifat deskriptif dengan rancangan survey cross sectional. Cara pengambilan sampel menggunakan teknik purposive sampling dengan jumlah sampel 46 responden menggunakan kriteria inklusi dan kriteria eksklusi. Hasil penelitian menunjukkan bahwa tingkat pengetahuan tentang karies gigi dan jumlah karies gigi pada siswa kelas IV SD Muhammadiyah Tegalrejo mayoritas memiliki tingkat pengetahuan tentang karies gigi kategori baik sebanyak 41 responden (91,1\%) dan jumlah karies gigi kategori sedang sebanyak 17 responden (37,8\%). Siswa kelas IV SD Muhammadiyah Tegalrejo memiliki tingkat pengetahuan tentang karies gigi kategori baik dan jumlah karies gigi kategori sedang sebanyak 15 responden (33,3\%).
\end{abstract}

Kata Kunci: Tingkat pengetahuan, Karies gigi 


\begin{abstract}
The level of knowledge is one of the common criteria that influences the attitude of maintaining the dental health of a person or community. The main problem with children's oral and dental health is dental caries. Dental caries is caused by bacterial metabolic activity in the plaque that causes email demineralization.

This study aims to find out the description the level of knowledge about dental caries and the number of dental caries in fourth grade students of SD Muhammadiyah Tegalrejo.

This type of research is descriptive with a cross sectional survey design. The method of sampling uses purposive sampling technique with a sample of 46 respondents using inclusion criteria and exclusion criteria.

The result showed that the majority of knowledge about dental caries and the number of dental caries in the fourth grade students of SD Muhammadiyah Tegalrejo had a good category of knowledge about dental caries in 41 respondents $(91,1 \%)$, and the number of dental caries for the medium category was 17 respondents $(37,8 \%)$.

The fourth grade students of SD Muhammadiyah Tegalrejo had a good level of knowledge about dental caries and the number of dental caries in medium category was 15 respondents $(33,3 \%)$.
\end{abstract}

Keywords: The Level of Knowledge, Dental Caries

\section{PENDAHULUAN}

Persentase penduduk yang mempunyai masalah kesehatan gigi dan mulut menurut Riset Kesehatan Dasar (Riskesdas) tahun 2007 dan 2013 meningkat dari $23,2 \%$ menjadi 25,9\%. ${ }^{1}$ Riset Kesehatan Dasar tahun 2013 menunjukkan bahwa kelompok umur 5-9 tahun terdapat $28,9 \%$ mempunyai masalah kesehatan gigi dan mulut, dan kelompok umur 1014 tahun terdapat $25,2 \%$ mempunyai masalah kesehatan gigi dan mulut.

Tingkat pengetahuan merupakan salah satu kriteria umum yang mempengaruhi sikap menjaga kesehatan gigi seseorang atau komunitas. Pengetahuan yang baik dapat mempengaruhi perilaku kesehatan dalam meningkatkan kesehatan khususnya kesehatan gigi dan mulut. Sebaliknya, pengetahuan yang kurang mengenai pentingnya pemeliharaan gigi dan mulut dapat menyebabkan timbulnya sikap mengabaikan kebersihan gigi dan mulut. $^{2}$ Pengetahuan adalah hasil penginderaan manusia, atau hasil tahu seseorang terhadap objek melalui indera yang dimilikinya (mata, hidung, telinga, dan sebagainya). Sebagian besar pengetahuan seseorang diperoleh melalui indera pendengaran (telinga), dan indera penglihatan (mata). Pengetahuan seseorang terhadap 
objek mempunyai intensitas atau tingkat yang berbeda-beda. ${ }^{3}$

Masalah utama kesehatan gigi dan mulut anak ialah karies gigi. ${ }^{4}$ Karies gigi atau gigi berlubang adalah suatu penyakit pada jaringan keras gigi yang ditandai rusaknya email dan dentin disebabkan oleh aktivitas metabolisme bakteri dalam plak yang menyebabkan terjadinya demineralisasi akibat interaksi antar produk-produk mikroorganisme,

\section{METODE PENELITIAN}

Jenis penelitian ini bersifat deskriptif, yaitu untuk mendeskripsikan atau menguraikan suatu kejadian di dalam masyarakat ludah, dan bagian-bagian yang berasal dari makanan dan email. ${ }^{5}$

Tujuan dari penelitian ini adalah untuk mengetahui gambaran tingkat pengetahuan tentang karies gigi dan jumlah karies gigi pada siswa kelas IV SD Muhammadiyah Tegalrejo. Secara khusus, tujuan penelitian ini adalah untuk mengetahui tingkat pengetahuan tentang karies gigi dan jumlah karies gigi pada siswa kelas IV SD Muhammadiyah Tegalrejo.

dengan rancangan survey cross sectional, yaitu dengan pengamatan sesaat atau dalam periode tertentu dan setiap subjek studi hanya dilakukan satu kali pengamatan selama penelitian. ${ }^{6}$

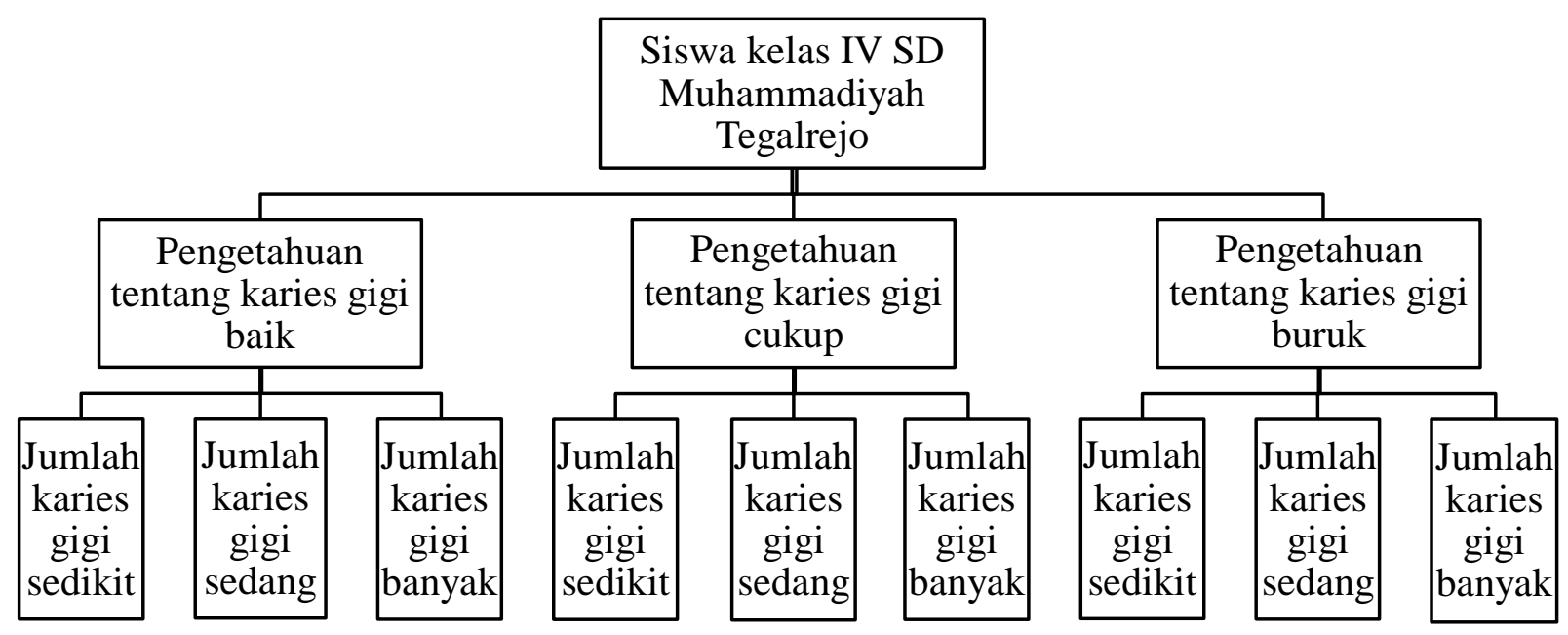

Gambar 1: Desain Penelitian

Pengambilan sampel dalam penelitian ini menggunakan teknik purposive sampling, yaitu kelas IV
SD Muhammadiyah Tegalrejo yang berjumlah 46 siswa. Kriteria dalam pengambilan sampel pada penelitian 
ini adalah kriteria inklusi yaitu bersedia menjadi responden dan kriteria eksklusi yaitu tidak hadir saat penelitian.

Penelitian ini dilaksanakan di SD Muhammadiyah Tegalrejo pada Bulan Februari 2019. Aspek yang diteliti dalam penelitian ini adalah pengetahuan tentang karies gigi dan jumlah karies gigi. Metode pengumpulan data yang digunakan untuk mengetahui tingkat pengetahuan tentang karies gigi dan jumlah karies gigi pada siswa kelas IV SD Muhammadiyah Tegalrejo dengan menggunakan kuesioner dan pemeriksaan jumlah karies gigi. Data disajikan dalam bentuk tabulasi silang (crosstabs).

\section{HASIL PENELITIAN}

Tabel 1. Karakteristik Responden Berdasarkan Jenis Kelamin

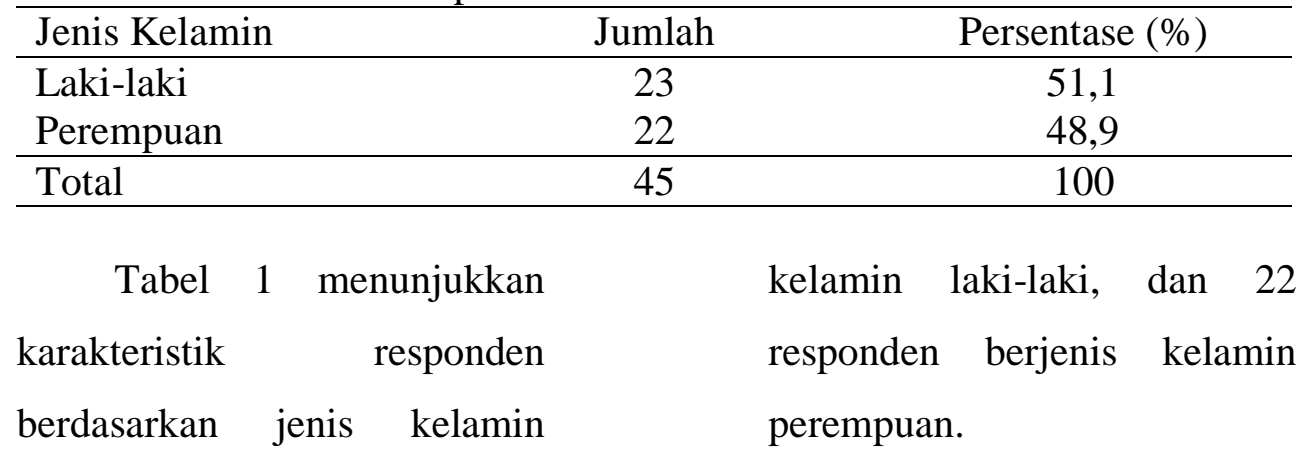

yaitu 23 responden berjenis

Tabel 2. Karakteristik Responden Berdasarkan Umur

\begin{tabular}{ccc}
\hline Umur (Tahun) & Jumlah & Persentase $(\%)$ \\
\hline 9 & 7 & 15,6 \\
10 & 38 & 84,4 \\
\hline Total & 45 & 100 \\
\hline
\end{tabular}

Tabel 2 menunjukkan

karakteristik responden

berdasarkan umur bahwa dari

Tabel 3. Distribusi Responden Berdasarkan Tingkat Pengetahuan Tentang Karies Gigi
45 responden sebagian besar berumur 10 tahun sebanyak 38 responden $(84,4 \%)$.

\section{Tentang Karies Gigi}

Jumlah Persentase (\%)




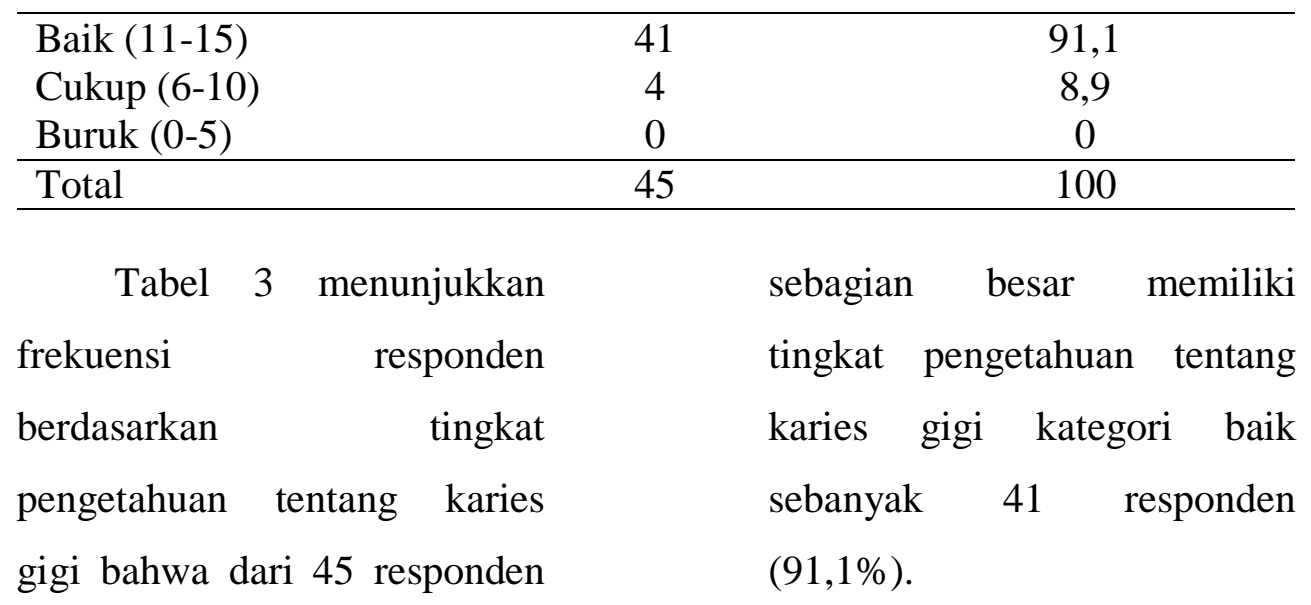

Tabel 4. Distribusi Responden Berdasarkan Jumlah Karies Gigi

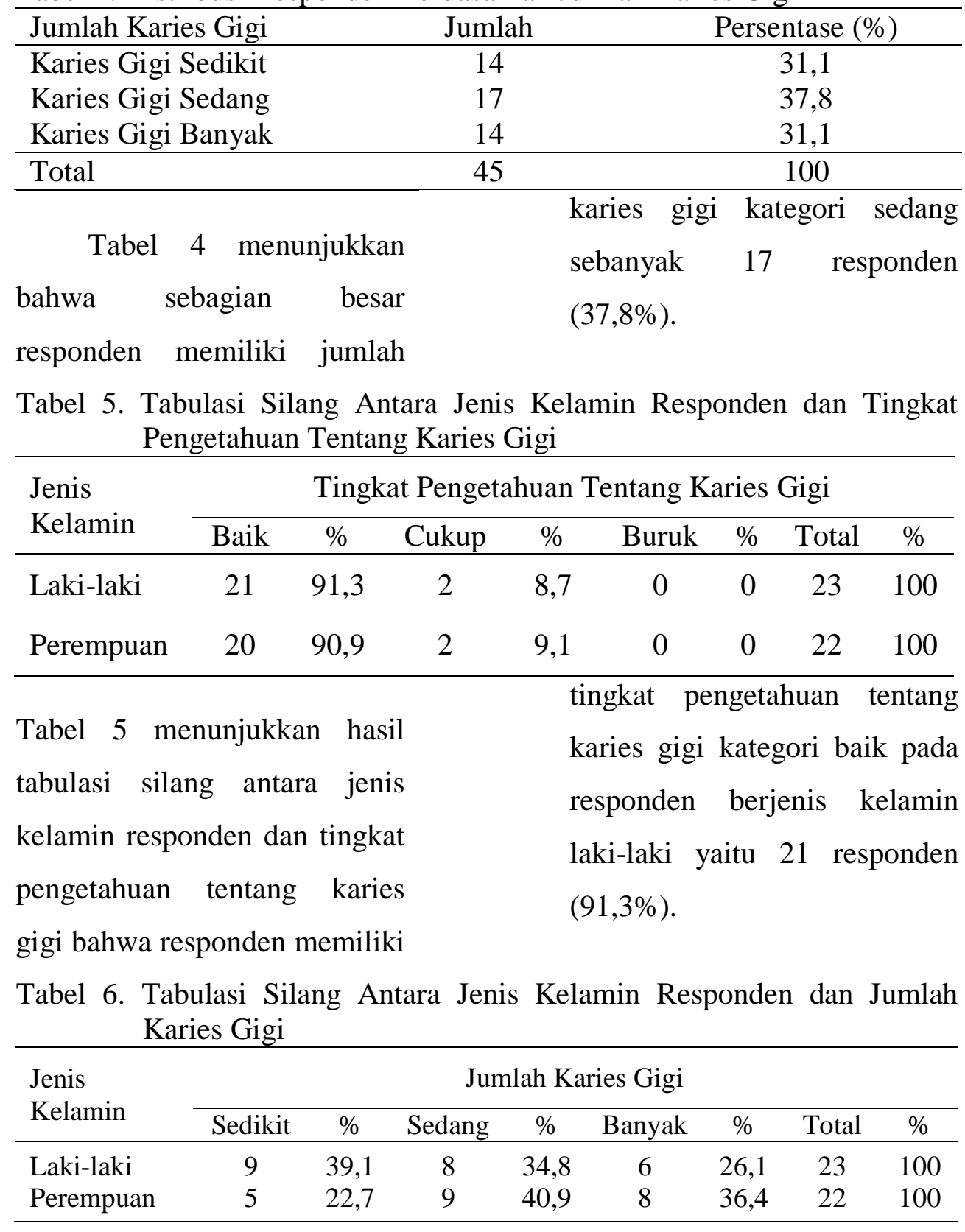


Tabel 6 menunjukkan hasil tabulasi silang antara jenis kelamin responden dan jumlah karies gigi bahwa responden memiliki jumlah karies gigi dengan kategori sedang pada responden perempuan sebanyak 9 responden $(40,9 \%)$.

Tabel 7. Tabulasi Silang Antara Umur Responden dan Tingkat Pengetahuan Tentang Karies Gigi

\begin{tabular}{lcccccccc}
\hline \multirow{2}{*}{$\begin{array}{l}\text { Umur } \\
\text { (Tahun) }\end{array}$} & \multicolumn{7}{c}{ Tingkat Pengetahuan Tentang Karies Gigi } \\
\cline { 2 - 9 } & Baik & $\%$ & Cukup & $\%$ & Buruk & $\%$ & Total & $\%$ \\
\hline 9 & 4 & 57,1 & 3 & 42,9 & 0 & 0 & 7 & 100 \\
10 & 37 & 97,4 & 1 & 2,6 & 0 & 0 & 38 & 100 \\
\hline
\end{tabular}

Tabel 7 menunjukkan hasil tabulasi silang antara umur responden dan tingkat pengetahuan tentang karies gigi bahwa responden memiliki tingkat pengetahuan tentang karies gigi kategori baik pada responden berumur 10 tahun sebanyak 37 responden $(97,4 \%)$.

Tabel 8. Tabulasi Silang Antara Umur Responden dan Jumlah Karies Gigi

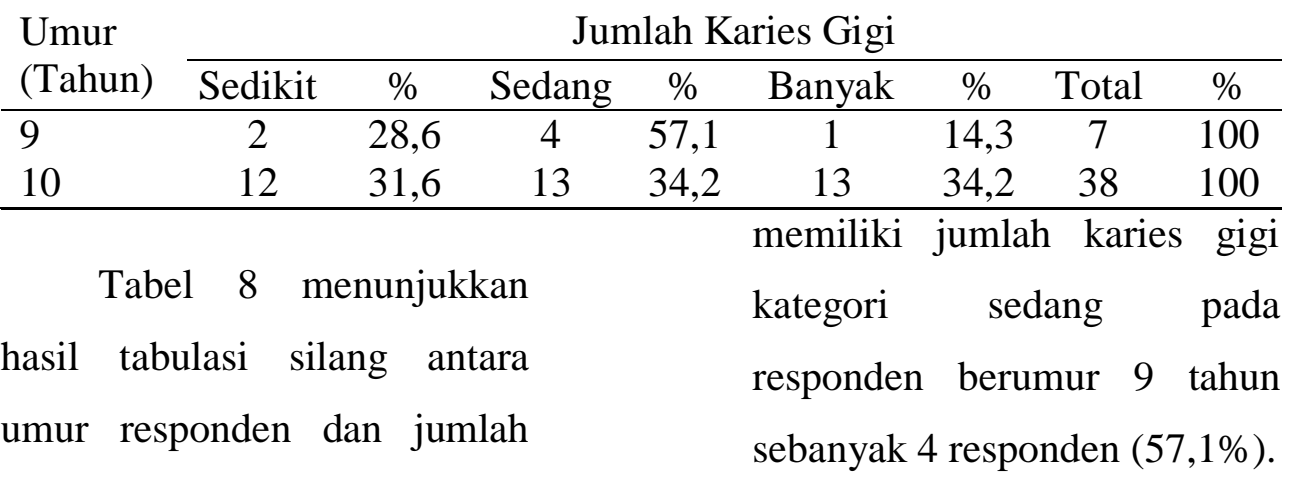

karies gigi bahwa responden

Tabel 9. Tabulasi Silang Antara Tingkat Pengetahuan Tentang Karies Gigi dan Jumlah Karies Gigi

\begin{tabular}{|c|c|c|c|c|c|c|c|c|}
\hline \multirow{2}{*}{$\begin{array}{l}\text { Tingkat } \\
\text { Pengetahuan } \\
\text { Tentang } \\
\text { Karies Gigi }\end{array}$} & \multicolumn{8}{|c|}{ Jumlah Karies Gigi } \\
\hline & Sedikit & $\%$ & Sedang & $\%$ & Banyak & $\%$ & Total & $\%$ \\
\hline Baik & 12 & 26,7 & 15 & 33,3 & 14 & 31,1 & 41 & 91,1 \\
\hline Cukup & 2 & 4,4 & 2 & 4,4 & 0 & 0 & 4 & 8,9 \\
\hline Buruk & 0 & 0 & 0 & 0 & 0 & 0 & 0 & 0 \\
\hline Total & 14 & 31,1 & 17 & 37,8 & 14 & 31,1 & 45 & 100 \\
\hline
\end{tabular}

Tabel 9 menunjukkan hasil tabulasi silang antara tingkat pengetahuan tentang karies gigi dan jumlah karies 
gigi bahwa responden memiliki tingkat pengetahuan tentang karies gigi kategori baik

\section{PEMBAHASAN}

1. Karakteristik Responden

Tabel 1 menunjukkan sebagian besar responden berjenis kelamin laki-laki sebanyak 23 responden $(51,1 \%)$. Hal ini dikarenakan dari seluruh sampel penelitian didominasi oleh responden berjenis kelamin laki-laki dibanding perempuan. Responden berumur 10 tahun paling banyak ditemukan pada tabel 2 yaitu sebanyak 37 responden $(82,2 \%)$. Hal ini dikarenakan responden yang berumur 10 tahun paling banyak didapatkan pada kelas IV. Periode 6-12 tahun merupakan masa usia sekolah dasar, umur 10-12 tahun merupakan periode gigi bercampur, sehingga diperlukan tindakan yang baik untuk pemeliharaan kesehatan gigi dan mulut. Pada periode ini juga anak sudah menunjukkan kepekaan untuk belajar sesuai dengan rasa ingin tahunya, termasuk menyikat gigi. $^{7}$ dengan jumlah karies gigi kategori sedang sebanyak 15 responden

$(33,3 \%)$.

2. Tingkat Pengetahuan Tentang Karies Gigi

Responden dengan tingkat pengetahuan kategori baik (lihat tabel 3) sebanyak 41 responden $(91,1 \%)$. Hasil ini menunjukkan bahwa sebagian besar responden memiliki tingkat pengetahuan tentang karies gigi dengan kategori baik. Hal ini karena kemungkinan responden sudah pernah mendapatkan informasi tentang kesehatan gigi dan mulut dari media massa yaitu poster yang dipasang di sekolah oleh petugas kesehatan. Hasil penelitian ini didukung oleh penelitian yang menyatakan bahwa sebagian responden memiliki tingkat pengetahuan yang baik. Pengetahuan tentang kesehatan gigi tidak hanya didapat dari materi pembelajaran saja, akan tetapi bisa didapat melalui orang tua, saudara, maupun berbagai media massa seperti surat kabar, radio, televisi, dan juga poster-poster yang dipasang petugas kesehatan. 
Sehingga meningkatkan pengetahuan responden tentang kesehatan gigi meskipun pendidikannya masih dalam tahap dasar namun memiliki pengetahuan yang relatif baik. ${ }^{8}$

\section{Jumlah Karies Gigi}

Tabel 4 menunjukkan sebagian besar responden mempunyai jumlah karies gigi kategori sedang yaitu 17 responden $(37,8 \%)$. Kurangnya kesadaran responden terhadap pemeliharaan kesehatan gigi dan mulut kemungkinan menjadi faktor penyebab responden memiliki karies gigi walaupun masih dalam kategori sedang. Tingginya prevalensi karies gigi dapat disebabkan karena anak tidak menerapkan pengetahuan kesehatan gigi dan mulut dalam perilaku kesehatan gigi seharihari atau mungkin setelah memakan makanan coklat atau sejenisnya tidak menyikat gigi. Pengetahuan anak dalam memelihara kesehatan gigi dan mulutnya sangat penting untuk menjaga kebersihan rongga mulut dan mencegah terjadinya karies. ${ }^{9}$

4. Tabulasi Silang Antara Jenis Kelamin Responden dan Tingkat Pengetahuan Tentang Karies Gigi

Tabel 5 menunjukkan hasil tabulasi silang antara jenis kelamin responden dan tingkat pengetahuan tentang karies gigi bahwa responden laki-laki mempunyai tingkat pengetahuan dengan kategori baik sebanyak 21 responden $(91,3 \%)$ dan responden perempuan mempunyai tingkat pengetahuan dengan kategori baik sebanyak 20 responden (90,9\%). Hasil penelitian ini didukung oleh penelitian yang menyatakan beberapa orang beranggapan bahwa pengetahuan seseorang dipengaruhi oleh jenis kelaminnya. Pendapat ini sudah tertanam sejak zaman penjajahan. Namun hal itu di zaman sekarang sudah terbantahkan karena apapun jenis kelamin seseorang, bila masih produktif, berpendidikan, atau berpengalaman, maka akan cenderung mempunyai tingkat pengetahuan tinggi. ${ }^{10}$ 
5. Tabulasi Silang Antara Jenis Kelamin Responden dan Jumlah Karies Gigi Responden

Tabel 6 menunjukkan hasil tabulasi silang antara jenis kelamin responden dan jumlah karies gigi responden bahwa responden laki-laki memiliki jumlah karies gigi kategori sedikit sebanyak 9 responden $(39,1 \%)$ dan responden perempuan memiliki jumlah karies kategori sedang sebanyak 9 responden (40,9\%). Waktu erupsi gigi anak perempuan lebih cepat satu sampai enam bulan dibandingkan dengan anak laki-laki yang disebabkan oleh faktor hormonal berupa hormon esterogen. Kebiasaan anak perempuan yang lebih cenderung menyukai makanan manis dibandingkan dengan anak laki-laki juga merupakan salah satu faktor peningkatan karies yang lebih tinggi pada anak perempuan. Faktor-faktor inilah yang mungkin menjadi salah satu faktor penyebab peningkatan karies gigi pada anak perempuan. ${ }^{11}$ Hasil penelitian ini didukung oleh pengamatan yang dilakukan oleh Milahn-Turkeheim yang menyatakan bahwa karies gigi pada perempuan lebih tinggi dibanding dengan pria. ${ }^{12}$

6. Tabulasi Silang Antara Umur Responden dan Tingkat Pengetahuan Tentang Karies Gigi

Tabel 7 menunjukkan hasil tabulasi silang antara umur responden dan tingkat pengetahuan tentang karies gigi bahwa responden berumur 9 tahun mempunyai tingkat pengetahuan tentang karies gigi dengan kategori baik sebanyak 4 responden $(57,1 \%)$, responden berumur 10 tahun mempunyai tingkat pengetahuan tentang karies gigi dengan kategori baik sebanyak 37 responden (97,4\%). Hasil penelitian menunjukkan semakin bertambahnya usia dengan daya tangkap semakin meningkat, maka tingkat pengetahuan akan semakin baik. Umur berpengaruh dalam meningkatkan pengetahuan karena kemampuan mental yang diperlukan untuk mempelajari dan menyesuaikan dari situasi baru, 
seperti mengingat hal-hal yang dulu pernah dipelajari. ${ }^{10}$ Semakin bertambah usia akan semakin berkembang pula daya tangkap dan pola pikirnya sehingga pengetahuan yang diperoleh semakin baik. ${ }^{13}$

7. Tabulasi Silang Antara Umur Responden dan Jumlah Karies Gigi

Tabel 8 menunjukkan hasil tabulasi silang antara umur responden dan jumlah karies gigi bahwa sebagian besar responden berumur 9 tahun mempunyai jumlah karies gigi kategori sedang sebanyak 4 responden $(57,1 \%)$. Umumnya anak-anak memasuki usia sekolah mempunyai risiko karies yang yang tinggi, karena pada usia sekolah ini anak-anak biasanya suka jajan makanan dan minuman sesuai keinginannya. $^{4}$

8. Tabulasi Silang Antara Tingkat Pengetahuan Tentang Karies Gigi dan Jumlah Karies Gigi Siswa Kelas IV SD Muhammadiyah Tegalrejo
Hasil tabulasi silang antara tingkat pengetahuan tentang karies gigi dan jumlah karies gigi pada tabel 9 menunjukkan bahwa persentase tertinggi ada pada jumlah responden dengan tingkat pengetahuan kategori baik dan jumlah karies gigi kategori sedang sebanyak 15 responden $(33,3 \%)$. Hasil penelitian ini didukung oleh penelitian yang menyatakan bahwa tidak adanya hubungan yang kuat antara tingkat pengetahuan pemeliharaan kesehatan gigi dengan tingkat keparahan karies gigi, karena mengingat pengetahuan bukan merupakan satu-satunya faktor yang mempengaruhi tingkat keparahan karies gigi. Banyak faktor yang dapat menimbulkan karies gigi pada anak, di antaranya adalah faktor dalam mulut yang berhubungan langsung dengan proses terjadinya karies gigi antara lain; struktur gigi, morfologi gigi, susunan gigi-geligi dalam rahang, derajat keasaman saliva, kebersihan mulut yang berhubungan dengan frekuensi dan kebiasaan menyikat gigi, jumlah dan frekuensi makan makanan yang menyebabkan karies. Selain itu, terdapat faktor luar 
sebagai faktor predisposisi dan penghambat yang berhubungan tidak langsung dengan terjadinya karies gigi antara lain usia, jenis kelamin, letak geografis, tingkat ekonomi, serta pengetahuan, sikap, dan perilaku terhadap pemeliharaan kesehatan gigi. ${ }^{14}$ Keparahan karies disebabkan karena pengetahuan yang tinggi tidak optimal diterapkan dalam mendorong perilaku pemeliharaan kebersihan gigi dan mulut sehari-hari walaupun sudah memiliki pengetahuan kesehatan gigi dan mulut yang baik. Selain itu, pengetahuan yang diterima tidak semua bisa dipraktikkan karena terdapat faktor-faktor pendukung lain yang dapat mempengaruhi pengetahuan, misalnya peran orang tua, guru, faktor lingkungan, sosial, ekonomi, dan faktor lainnya. ${ }^{2}$

\section{KESIMPULAN}

Berdasarkan hasil penelitian dan pembahasan gambaran tingkat pengetahuan tentang karies gigi dan jumlah karies gigi pada kelas siswa IV SD Muhammadiyah Tegalrejo dengan jumlah 45 responden, dapat disimpulkan sebagai berikut.
1. Tingkat pengetahuan tentang karies gigi pada responden sebagian besar dengan kategori baik.

2. Jumlah karies gigi pada responden sebagian besar dengan kategori sedang.

3. Sebagian besar responden mempunyai tingkat pengetahuan tentang karies gigi kategori baik dengan jumlah karies gigi kategori sedang.

Pada penelitian ini diharapkan selanjutnya dapat melakukan penelitian dengan variabel-variabel yang lain dan sampel yang lebih banyak sehingga lebih mewakili populasi yang ada.

\section{UCAPAN TERIMA KASIH}

Terima kasih penulis ucapkan kepada:

1. Suharyono, S. Pd., S. SiT., M. Kes. selaku pembimbing utama

2. NS. Furaida Khasanah, M. Kep. selaku pembimbing pendamping

3. DR. drg. Wiworo Haryani, M. Kes. selaku Ketua Penguji Seminar Karya Tulis Ilmiah

4. Seluruh guru dan karyawan SD Muhammadiyah Tegalrejo

5. Seluruh responden penelitian 


\section{DAFTAR PUSTAKA}

1. Infodatin. 2014. Pusat Data dan Informasi Situasi Kesehatan Gigi dan Mulut Kementerian Kesehatan RI. Jakarta.

2. Rahtyanti, G, C, S, H, Hadnyanawati, dan E, Wulandari. 2018. Hubungan Pengetahuan Kesehatan Gigi dan Mulut dengan Karies Gigi pada Mahasiswa Baru Fakultas Kedokteran Gigi Universitas Jember Tahun Akademik 2016/2017. e-Jurnal Pustaka Kesehatan 6(1): 167-172.

3. Notoatmodjo, S. 2014. Ilmu Perilaku Kesehatan. Jakarta: Rineka Cipta.

4. Worotitjan, I, C, N, Mintjelungan, dan P, Gunawan. 2013. Pengalaman Karies Gigi serta Pola Makan dan Minum pada Anak Sekolah Dasar. Jurnal e-GiGi (eG) 1(1): 59-68.

5. Ramayanti, S dan I, Punakarya. 2013. Peran Makanan Terhadap Kejadian

Karies Gigi. Jurnal Kesehatan Masyarakat 7(2): 89-93.

6. Notoatmodjo, S. 2012. Metode Penelitian Kesehatan. Jakarta: Rineka Cipta.

7. Ningsih, S, U, T, Restuastuti, dan R, Endriani. 2016. Gambaran Pengetahuan dan Sikap Menyikat Gigi pada Siswa-Siswi dalam Mencegah Karies di SDN 005 Bukit Kapur Dumai. Jurnal Online Mahasisw FK. 3(2): 1-11.

8. Ardianti, E. 2017. Tingkat Pengetahuan Tentang Karies dan Status Karies pada Siswa Kelas
V SDN 1 Srandakan Bantul. Karya Tulis Ilmiah. Poltekkes Kemenkes Yogyakarta.

9. Rahmadhan, A, G. 2010. Serbaserbi Kesehatan Gigi dan Mulut. Jakarta: Bukune.

10. Khasanah, N. 2017. Gambaran Tingkat Pengetahuan Tentang Karies Gigi dan Jumlah Karies Gigi pada Siswa Sekolah Dasar. Karya Tulis Ilmiah. Poltekkes Kemenkes Yogyakarta.

11. Mangkey, E, J, Posangi, dan M, A, Leman. 2015. Gambaran Status Karies pada Siswa SMP Negeri 1 Tomohon. Jurnal eGiGi (eG) 3(1): 182-188.

12. Tarigan, R. 2013. Karies Gigi Edisi 2. Jakarta: EGC.

13. Notoatmodjo, S. 2007. Kesehatan Masyarakat Ilmu dan Seni. Jakarta: Rineka Cipta.

14. Lintang, J, Ch, H, Palandeng, dan M, A, Leman. 2015. Hubungan Tingkat Pengetahuan Pemeliharaan Kesehatan Gigi dan Tingkat Keparahan Karies Gigi Siswa SDN Tumaluntung Minahasa Utara. Jurnal e-GiGi (eG) 3(2): 567-572. 